1 MSF

Cite this as: BMJ 2021;375:n2962 http://dx.doi.org/10.1136/bmj.n2962 Published: 30 November 2021

\title{
The UK government's migration policy plans will only cause more suffering and death
}

\section{Sophie McCann advocacy officer}

On Wednesday 24 November 2021, at least 27 people, including three children and a pregnant woman, lost their lives attempting to cross the English Channel. Their deaths are a tragedy and my heart goes out to their families, friends, and loved ones. As well as sorrow I also feel immense anger and outrage that they lost their lives. It did not have to be this way.

I am horrified to see the UK government react by doubling down on their new plan for immigration: to implement punitive policies aimed at deterring people from reaching UK shores, instead of urgently providing assistance and protection to vulnerable people by opening up safe and legal routes for them to reach the UK. ${ }^{1}$

Over the last eight months, Priti Patel, the home secretary, and the Home Office have laid out these policies to be implemented through the new proposed Nationality and Borders Bill.

In its current form, this bill will open the door for this government to send refugees and asylum seekers to detention centres in another country to process their asylum claim, just like the Australian government has done on the Pacific Island of Nauru, through a policy known as offshore processing.

In 2017-18, Médecins Sans Frontières/Doctors Without Borders (MSF) ran a mental healthcare project for people indefinitely detained on Nauru. There, our medical teams witnessed catastrophic mental health impacts of this policy which generated some of the worst suffering we have seen in our 50 years of existence. One-third of our asylum seeker and refugee patients attempted suicide and children as young as nine were found to have self-harmed, had suicidal thoughts, or attempted suicide.

As it stands, this bill will grant the government powers to push back small vessels headed for UK shores. A highly dangerous, harmful, and sometimes lethal tactic that would be disastrous if carried out in the Channel-the busiest shipping route in the world.

MSF teams on the Greek Islands, in Libya, and on our search and rescue boats in the Mediterranean have witnessed the often-deadly consequences of choosing not to rescue people, but instead pushing them back to sea. More than 1,300 people have drowned in the Mediterranean this year alone. For most, crossing dangerous seas is a last resort in a desperate attempt to reach safety.

Priti Patel also plans to build large scale reception centres to contain asylum seekers and refugees. Yet, we know that callously detaining refugees in squalid camps and centres does not prevent them from trying to reach safety, it only punishes some of the most vulnerable people in the world.

MSF staff have seen some of the world's worst examples of the containment and mistreatment of vulnerable refugees. From Libya, where people are trapped in overcrowded detention centres and subject to violence and torture, to the Greek islands, where I have seen children packed into dangerous, filthy prison-like reception centres, with little access to healthcare, clean water, a safe place to sleep and denied any semblance of a childhood.

I've witnessed first-hand the horrendous physical and mental suffering of men, women, and children, created by cruel migration policies that are designed to remove dignity and inflict misery. Just like the one the UK Government is currently planning.

The bill is ultimately doomed to fail in its quest to stop people coming to the UK irregularly because these harsh policies fail to recognise or resolve the reasons why people flee their homes in the first place.

The bill presumes a "pull factor" which draws people to the UK. Priti Patel has suggested it is hotel asylum accommodation that people seek when they embark on treacherous journeys to the UK, with other commentators speculating that takeaway pizza given to refugees in Kent is too great a privilege. This absurdity makes a mockery of the conflict, persecution, and poverty that may be pushing people to take such desperate measures.

We recently asked the Home Office to show us their evidence of these so-called "pull factors" under a Freedom of Information Request. Unsurprisingly, the Home Office could provide none.

What's more, the government has failed to provide alternative safe and legal routes for people to claim asylum, instead systematically shutting down the few options that did exist. Just last year, this government closed the only pathway enabling unaccompanied children already in Europe to come to the UK and receive protection.

We know that this bill will not work. It will only drive desperate people to risk more dangerous routes-the consequence of which we saw all too clearly last week.

What is needed are dignified, kind and fair migration policies that ensure no more people suffer as they seek safety. ${ }^{2}$ I fear Priti Patel's Nationality and Borders Bill will do the opposite.

Competing interests: SMC is an advocacy officer at MSF UK. She previously spent two years in Greece working as advocacy manager for MSF's migration project. 


\section{OPINION}

Provenance and peer review: commissioned, not peer reviewed

1 Priti Patel twitter: https://twitter.com/pritipatel/status/1463576644254371849

2 https://msf.org.uk/issues/tell-uk-government-fix-its-inhumane-borders-bill

This is an Open Access article distributed in accordance with the Creative Commons Attribution Non Commercial (CC BY-NC 4.0) license, which permits others to distribute, remix, adapt, build upon this work non-commercially, and license their derivative works on different terms, provided the original work is properly cited and the use is non-commercial. See: http://creativecommons.org/licenses/bync/4.0/. 